\title{
Source Indication and Geochemical Significance of Sedimentary Organic Matters from the Xisha Area, the South China Sea
}

\author{
Yan Li ${ }^{1}$, Qian-Zhi Zhou ${ }^{1} \mathbb{1}$, Xiang-Po Xu ${ }^{1}$, Yun-Xin Fang ${ }^{2, *}$, Jin-Zhong Liu ${ }^{3}$ and Jiang-Hai Wang ${ }^{1, * \mathbb{D}}$ \\ 1 Guangdong Provincial Key Laboratory of Marine Resources and Coastal Engineering, School of Marine \\ Sciences, Sun Yat-sen University, Zhuhai 519082, China; liyan255@mail.sysu.edu.cn (Y.L.); \\ zhouqzhi@mail2.sysu.edu.cn (Q.-Z.Z.); xuxp35@mail2.sysu.edu.cn (X.-P.X.) \\ 2 Guangzhou Marine Geological Survey, Guangzhou 510760, China \\ 3 State Key Laboratory of Organic Geochemistry, Guangzhou Institute of Geochemistry, Chinese Academy of \\ Sciences, Guangzhou 510640, China; liujinz@gig.ac.cn \\ * Correspondence: fangyunxin@hydz.cn (Y.-X.F.); wangihai@mail.sysu.edu.cn (J.-H.W.)
}

check for updates

Citation: Li, Y.; Zhou, Q.-Z.; Xu, X.-P.; Fang, Y.-X.; Liu, J.-Z.; Wang, J.-H. Source Indication and Geochemical Significance of Sedimentary Organic Matters from the Xisha Area, the South China Sea. Molecules 2021, 26, 6808. https://doi.org/10.3390/ molecules26226808

Academic Editor:

Alessandra Guerrini

Received: 3 October 2021

Accepted: 8 November 2021

Published: 11 November 2021

Publisher's Note: MDPI stays neutral with regard to jurisdictional claims in published maps and institutional affiliations.

Copyright: (C) 2021 by the authors. Licensee MDPI, Basel, Switzerland. This article is an open access article distributed under the terms and conditions of the Creative Commons Attribution (CC BY) license (https:// creativecommons.org/licenses/by/ $4.0 /)$.

\begin{abstract}
Although various geochemical and geophysical investigations have already indicated a great resource potential in the Xisha area of the South China Sea, the origin of organic matter and molecular evidence for tracing the migration of hydrocarbons from deep petroleum reservoirs are still lacking. In this study, systematic organic geochemical analyses, including bulk organic matter parameters and lipid biomarkers were performed for deep sediments from two cores. The $\mathrm{C} / \mathrm{N}$ ratios and $\delta^{13} \mathrm{C}$ and $\delta^{15} \mathrm{~N}$ values of organic matter in most of the samples, together with the maxima of short-chain $n$-alkanoic acids and mid-chain $n$-alkanols, high abundances of monounsaturated fatty acids $C_{18: 1 \omega 9}$ and $C_{22: 1 \omega 13}$, jointly indicate the dominance of marine organic matter. $n$-Alkanes in sediments from core GMGS4-XH-W06B are characterized by small unresolved complex mixture (UCMs) humps, high odd/even predominance (OEP) and carbon preference index (CPI) values, clearly exhibiting characteristics of modern sediments. However, the sediments for core GMGS4-XH-W03B are featured with big UCMs, associated with OEP and CPI values around 1.0, showing signatures of petroleum hydrocarbons from high maturity sources. Considering the geologic background, the biomarker signatures are solid evidence for indicating the existence of underlying petroleum reservoirs, and may provide the valuable information for assessing the hydrocarbon resources in the Xisha area.
\end{abstract}

Keywords: source indication; sedimentary organic matter; biomarkers; petroleum hydrocarbons; Xisha area; South China Sea

\section{Introduction}

The South China Sea (SCS) is located at the confluence of the Pacific, Eurasian, and Indian-Australian plates, and was formed during the late Jurassic-early Cretaceous [1]. It harbors numerous natural gas hydrates and conventional gas/oil reservoirs [2-4]. In light of the great gas hydrate and petroleum/gas reservoir potential, as well as the significant environmental effects (e.g., global warming and petroleum/gas exploration), the SCS has attracted the increasing attention of marine geologists and geochemists [5-7].

Recently, many oil/gas fields have been found in the SCS, such as the Beibu Gulf Basin, Pearl River Mouth Basin and Wan'An Basin [8]. The prospecting areas of gas hydrates, such as Dongsha, Xisha, Qiongdongnan and Shenhu, were firstly determined via the extension of bottom-simulating reflectors (BSRs) $[9,10]$. After several hydrate survey expeditions, some hydrate-bearing areas, e.g., Dongsha and Shenhu, have further been confirmed [7,10,11]. In addition, numerous cold seeps have also been discovered in the Dongsha and Shenhu areas, indicating the hydrocarbon seepage and occurrence of underlying gas hydrates [5]. In these areas, many studies have been conducted, mainly including geochemistry, geophysics, numerical simulation, sediment fabrics, microbial diversity, and biomarkers [7,11-19]. 
Notably, the contribution of petroleum hydrocarbons from deep oil reservoirs in these areas was revealed by the analyses of $16 \mathrm{~S}$ rRNA and biomarkers $[7,11,19]$.

The Xisha area, adjacent to many oil and gas fields, is located in the northern slope of the SCS. This area is characterized by high sedimentation rates and steep geothermal gradients. As a result, overpressures occur in sedimentary strata and the maturity of their organic matters in this area was enhanced, thereby a large amount of hydrocarbons were formed and migrated toward the seabed [20]. To our knowledge, no gas hydrates have been found in the Xisha area, despite the BSRs, porewater characteristics and the occurrence of pockmarks suggest a great resource potential [20-22]. During the last decades, numerous studies have been conducted in this area, but their attention was mainly focused on the formation of carbonates and their paleoclimate evolution [23,24], and no direct investigation on the organic geochemical evidence related to a source indication for verifying the existence of petroleum/gas reservoirs and gas hydrates in the Xisha area has been reported. Therefore, we still do not clearly know the characteristics of sedimentary organic matter in this area, which may provide important information for identifying gas hydrate and petroleum/gas reservoirs.

The information of sedimentary organic matter, such as bulk organic matter parameters and lipid biomarker signatures, may provide insight into the original source inputs [25-28]. It is notable that pollution is correlated with organic matters as reported from previous studies [29-31]. In the present work, the deep sediments from two cores (GMGS4-XH-W03B and GMGS4-XH-W06B) from gas hydrate drilling expeditions in the Xisha area of the SCS were selected for systematically performing organic geochemical analysis (Table 1; Figure 1), including total organic carbon (TOC) and total nitrogen (TN) contents, $\mathrm{C} / \mathrm{N}$ ratios, and $\delta^{13} \mathrm{C}$ and $\delta^{15} \mathrm{~N}$ values, as well as biomarker (i.e., $n$-alkanes, $n$-alkanols, steroids, and fatty acids) distribution patterns and sedimentary organic matter compositions. Notably, oil stains were observed in sample 2 from core GMGS4-XH-W03B (Figure 2). The purpose of this study is to compare the origin of the organic matter and determine oil/gas seepage signatures for evaluating the potentials of underlying gas hydrates and conventional oil/gas reservoirs.

Table 1. Sample information.

\begin{tabular}{|c|c|c|c|c|c|}
\hline Stations & $\begin{array}{c}\text { Water } \\
\text { Depth (m) }\end{array}$ & $\begin{array}{c}\text { Geothermal } \\
\text { Gradients } \\
\left({ }^{\circ} \mathrm{C} / \mathrm{km}\right)\end{array}$ & $\begin{array}{l}\text { SMI Depth } \\
\text { (m) }\end{array}$ & $\begin{array}{l}\text { Sample } \\
\text { ID }\end{array}$ & $\begin{array}{l}\text { Depth } \\
\text { (cmbsf) }\end{array}$ \\
\hline \multirow{3}{*}{$\begin{array}{l}\text { GMGS4-XH- } \\
\text { W03B }\end{array}$} & \multirow{3}{*}{1777} & \multirow{3}{*}{72} & \multirow{3}{*}{70} & 1 & $47,150-47,160$ \\
\hline & & & & 2 & $49,933-49,946$ \\
\hline & & & & 3 & $52,150-52,160$ \\
\hline \multirow{2}{*}{$\begin{array}{l}\text { GMGS4-XH- } \\
\text { W06B }\end{array}$} & \multirow{2}{*}{1923} & \multirow{2}{*}{89} & \multirow{2}{*}{150} & 4 & $25,250-25,260$ \\
\hline & & & & 5 & $27,350-27,360$ \\
\hline
\end{tabular}

Notes: SMI represents the sulfate-methane interface. 


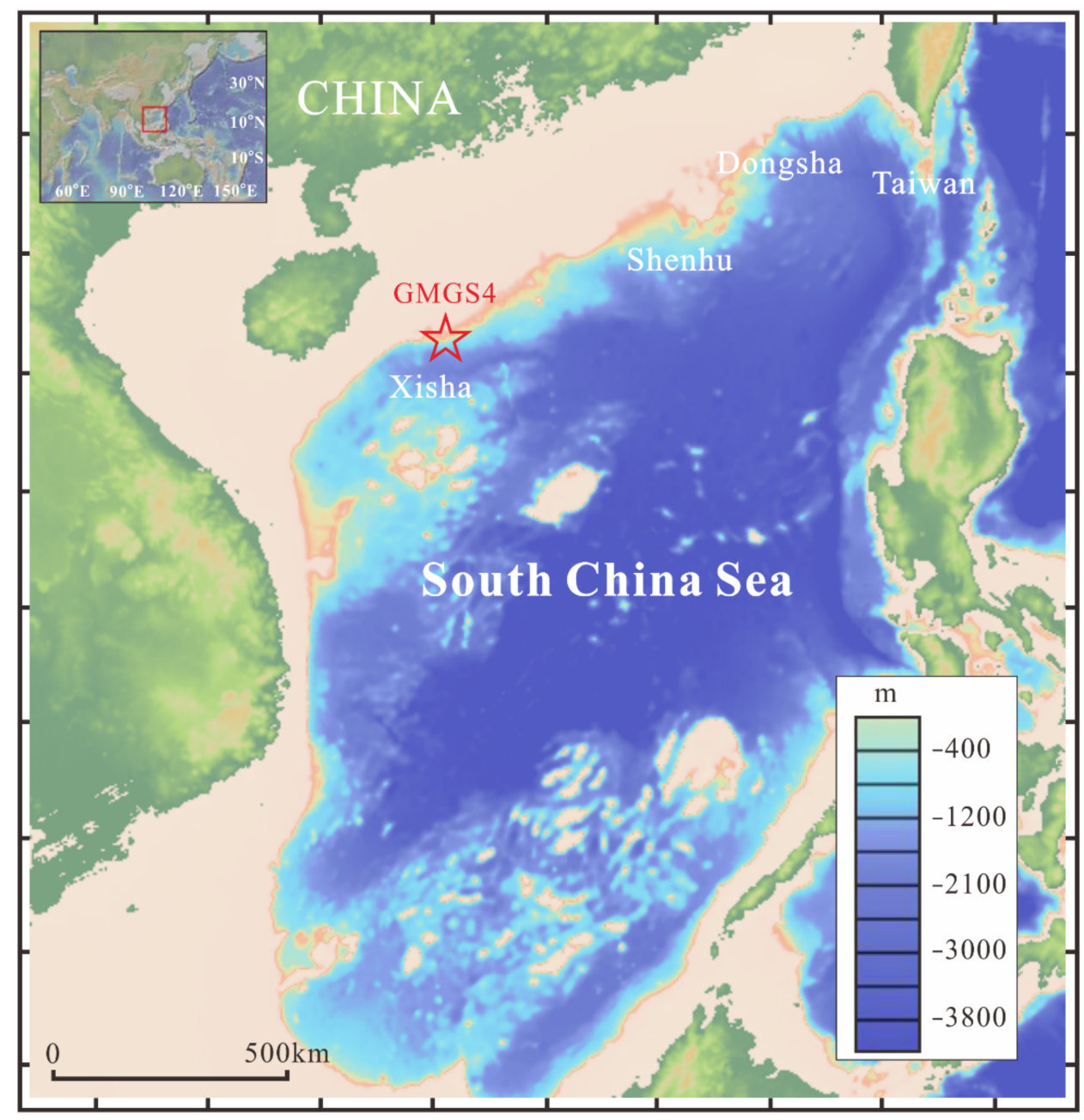

Figure 1. Map illustrating the locations of sediment cores GMGS4-XH-W03B and GMGS4-XH-W06B from the Xisha area, the South China Sea (SCS) (Adapted with permission from ref. [5]. Copyright 2018 Clearance Center).

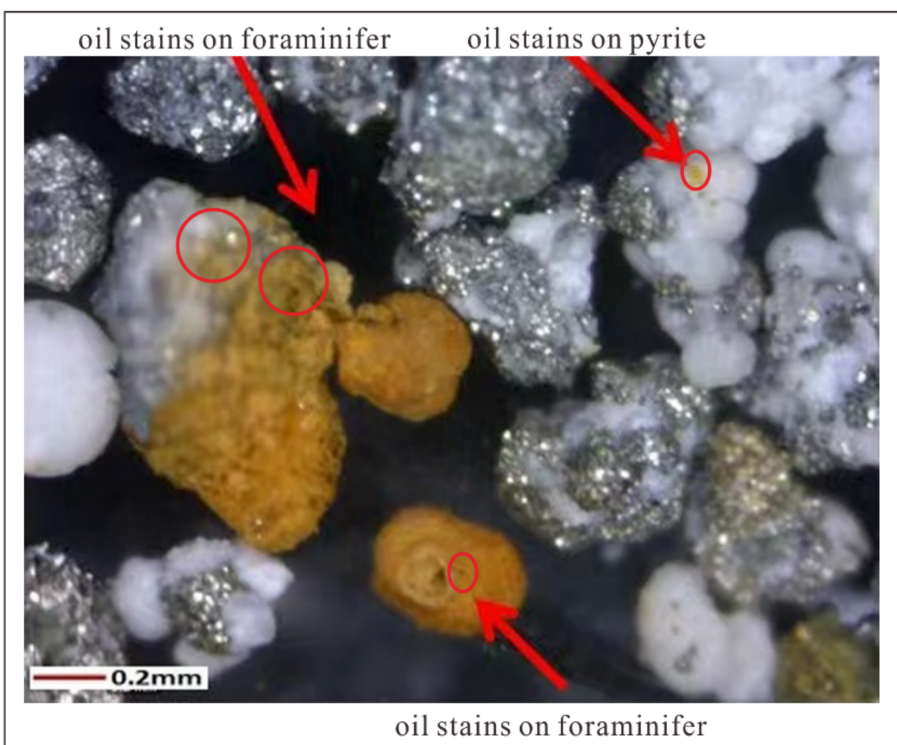

Figure 2. Oil stains in sample 2 from core GMGS4-XH-W03B. Red arrows reflect the direction indicated by the comment text; red circles suggest the locations of oil stains. 


\section{Results}

The TOC and TN contents, $\mathrm{C} / \mathrm{N}$ ratios, and $\delta^{13} \mathrm{C}$ and $\delta^{15} \mathrm{~N}$ values are presented in Table 2 and Figure 3. The TOC contents of the samples from cores GMGS4-XH-W03B and GMGS4-XH-W06B are about $0.30 \%$ and $0.50 \%$, respectively. The TN contents in the samples from two cores range from $0.06 \%$ to $0.09 \%$. The atomic $\mathrm{C} / \mathrm{N}$ ratios in the samples from core GMGS4-XH-W03B are at the interval of 3.46 to 4.65; while those for core GMGS4-XH-W06B range from 5.40 to 6.00 . The difference between the $\mathrm{C} / \mathrm{N}$ ratios of both core samples is mainly due to their TOC contents rather than TN contents. The $\delta^{13} \mathrm{C}$ and $\delta^{15} \mathrm{~N}$ values of the samples from core GMGS4-XH-W03B are in the range of $-23.65 \%$ to $-22.20 \%$ and $3.43 \%$ to $5.08 \%$, respectively; whereas those for core GMGS4-XH-W06B are from $-22.07 \%$ to $-21.81 \%$ and $4.68 \%$ to $4.71 \%$, respectively. As a whole, the TOC and TN contents and $\mathrm{C} / \mathrm{N}$ ratios in the studied samples are nearly similar, but those in the samples from core GMGS4-XH-W06B are slightly higher. Except sample 3 in core GMGS4-XH-W03B, both $\delta^{13} \mathrm{C}$ and $\delta^{15} \mathrm{~N}$ values are comparable in the two cores. In addition, a strong positive correlation between the $\delta^{13} \mathrm{C}$ and $\delta^{15} \mathrm{~N}$ values exhibits for our data set (Figure 3f). For the bulk organic carbon/nitrogen and their stable isotope values, it is interesting that there is no difference in the sample with oil stains.

Table 2. Analytical results of the bulk geochemical parameters and biomarker ratios for sediment cores.

\begin{tabular}{|c|c|c|c|c|c|}
\hline \multirow{2}{*}{$\begin{array}{c}\text { Stations } \\
\text { Sample ID }\end{array}$} & \multicolumn{3}{|c|}{ GMGS4-XH-W03B } & \multicolumn{2}{|c|}{ GMGS4-XH-W06B } \\
\hline & 1 & 2 & 3 & 4 & 5 \\
\hline TOC (\%) & 0.29 & 0.31 & 0.28 & 0.50 & 0.53 \\
\hline $\mathrm{TN}(\%)$ & 0.08 & 0.07 & 0.06 & 0.09 & 0.09 \\
\hline $\mathrm{C} / \mathrm{N}$ ratios & 3.46 & 4.58 & 4.65 & 5.40 & 6.00 \\
\hline$\delta^{13} \mathrm{C}(\%)$ & -22.22 & -22.20 & -23.65 & -22.07 & -21.81 \\
\hline$\delta^{15} \mathrm{~N}(\%$ o $)$ & 5.08 & 4.91 & 3.43 & 4.71 & 4.68 \\
\hline$F_{\text {ter }}(\%)$ & 26 & 26 & 48 & 24 & 20 \\
\hline \multicolumn{6}{|c|}{ n-Alkanes } \\
\hline Carbon ranges & $\mathrm{C}_{21}-\mathrm{C}_{31}$ & $\mathrm{C}_{17}-\mathrm{C}_{32}$ & $\mathrm{C}_{21}-\mathrm{C}_{31}$ & $\mathrm{C}_{17}-\mathrm{C}_{29}$ & $\mathrm{C}_{23}-\mathrm{C}_{31}$ \\
\hline $\mathrm{Cx}$ & $\mathrm{C}_{27}$ & $\mathrm{C}_{25}$ & $\mathrm{C}_{25}$ & $\mathrm{C}_{27}$ & $\mathrm{C}_{29}$ \\
\hline Size of UCMs hump & big & big & small & small & small \\
\hline $\mathrm{CPI}_{24-33}$ & 1.15 & 1.35 & 1.14 & 2.92 & 2.33 \\
\hline $\mathrm{OEP}(i=23)$ & 1.08 & 1.18 & 1.05 & 1.98 & 1.97 \\
\hline $\mathrm{C}_{21-} / \mathrm{C}_{22+}$ & 0.01 & 0.08 & 0.02 & 0.28 & 0.00 \\
\hline \multicolumn{6}{|c|}{ Fatty acids } \\
\hline Carbon ranges & $\mathrm{C}_{12}-\mathrm{C}_{22}$ & $\mathrm{C}_{12}-\mathrm{C}_{30}$ & $\mathrm{C}_{14}-\mathrm{C}_{22}$ & $\mathrm{C}_{12}-\mathrm{C}_{28}$ & n.a \\
\hline$C x$ & $\mathrm{C}_{16}$ & $\mathrm{C}_{16}$ & $\mathrm{C}_{16}$ & $\mathrm{C}_{16}$ & n.a \\
\hline$i-C_{15: 0}+a i-C_{15: 0} / C_{15: 0}$ & n.d & 1.1 & n.d & 0.4 & n.a \\
\hline \multicolumn{6}{|c|}{ n-Alkanols } \\
\hline Carbon ranges & $\mathrm{C}_{16}-\mathrm{C}_{28}$ & $\mathrm{C}_{18}-\mathrm{C}_{28}$ & n.a & n.a & $\mathrm{C}_{16}-\mathrm{C}_{28}$ \\
\hline$C x$ & $\mathrm{C}_{22}$ & $\mathrm{C}_{28}$ & n.a & n.a & $\mathrm{C}_{24}$ \\
\hline
\end{tabular}

Notes: $F_{\text {ter }}(\%)$ represents the percent contribution of terrestrial organic matters. $\mathrm{C}_{x}=$ Dominant carbon number; $\mathrm{CPI}_{25-33}=1 / 2\left[\Sigma\left(\mathrm{C}_{25}-\mathrm{C}_{33}\right)_{\text {odd }} / \Sigma\left(\mathrm{C}_{24}-\mathrm{C}_{32}\right)_{\text {even }}+\Sigma\left(\mathrm{C}_{25}-\mathrm{C}_{33}\right)_{\text {odd }} / \Sigma\left(\mathrm{C}_{26}-\mathrm{C}_{34}\right)_{\text {even }}\right] ; \mathrm{OEP}=\left[\left(\mathrm{C}_{i}+6 \mathrm{C}_{i+2}+\right.\right.$ $\left.\left.\mathrm{C}_{i+4}\right) /\left(4 \mathrm{C}_{i+1}+4 \mathrm{C}_{i+3}\right)\right]^{(-1) i+1}, i=23$; n.d., not detected; and n.a., not acquired. 

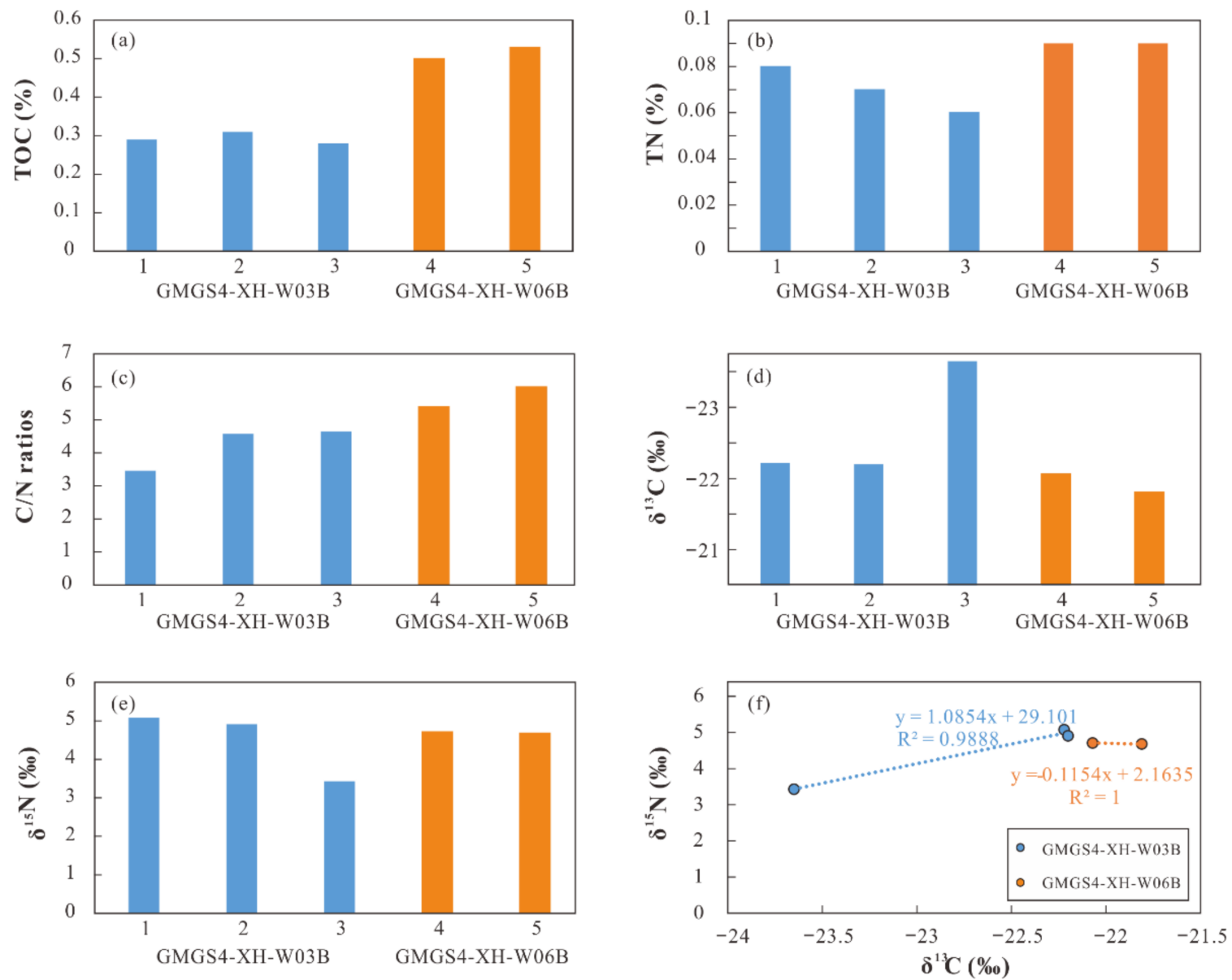

Figure 3. (a) TOC contents; (b) TN contents; (c) C/N ratios; (d) $\delta^{13} \mathrm{C}$ values; (e) $\delta^{15} \mathrm{~N}$ values; and (f) cross-plot of the $\delta^{13} \mathrm{C}$ and $\delta^{15} \mathrm{~N}$ values in sediments.

The signatures of $n$-alkanes in the samples from two cores display similarities and differences to some extent (Table 2; Figure 4). As a whole, the $n$-alkanes in all samples are mainly distributed in the range of $n-\mathrm{C}_{17}$ to $n-\mathrm{C}_{31}$; short-chain $n$-alkanes are relatively low in abundance (the $\mathrm{C}_{21-} / \mathrm{C}_{22+}$ values less than 0.28 ). Notably, the samples from core GMGS4$\mathrm{XH}-\mathrm{W} 03 \mathrm{~B}$ are primarily characterized by the dominance of medium-chain $n$-alkanes with a maximum at $n-\mathrm{C}_{25}$; and the humps of unresolved complex mixture (UCMs) occur in most of them, particularly the occurrence of big UCMs humps in the sample with oil stains. While $n$-alkanes in the samples from core GMGS4-XH-W06B are generally in low abundances with small UCMs humps, and dominated by long-chain $n$-alkanes with a maximum at $n$ - $\mathrm{C}_{27}$ and $n-\mathrm{C}_{29}$. The carbon preference indices (CPI) and odd/even predominance ratios (OEP, $\left.i=23\right)$ are around 1.0 in the samples from core GMGS4-XH-W03B; while those for the samples from core GMGS4-XH-W06B are at the interval of 2.33 to 2.92 and 1.97 to 1.98 , respectively, with the odd-over-even carbon number predominance. The biomarkers, such as pristane, phytane, steranes and hopanes, are useful to provide the significant information on the source inputs and thermal maturity, and may hold clues on the oil/source correlation since they can be steadily detected from oil/gas reservoirs [27]. Unfortunately, pristane and phytane are usually below detection lines, and only recognized in a few samples but with low abundances. It is noteworthy that terpanes and steranes are undetectable, which is similar to the previous result that the conventional GC-MS could not clearly identify these biomarkers due to their low abundances [7]. Therefore, indicators of thermal maturity such as $\mathrm{Ts} /(\mathrm{Ts}+\mathrm{Tm})$ and $\mathrm{C}_{29} 20 \mathrm{~S} /(20 \mathrm{~S}+20 \mathrm{R})$ sterane ratios cannot be acquired in this study. 

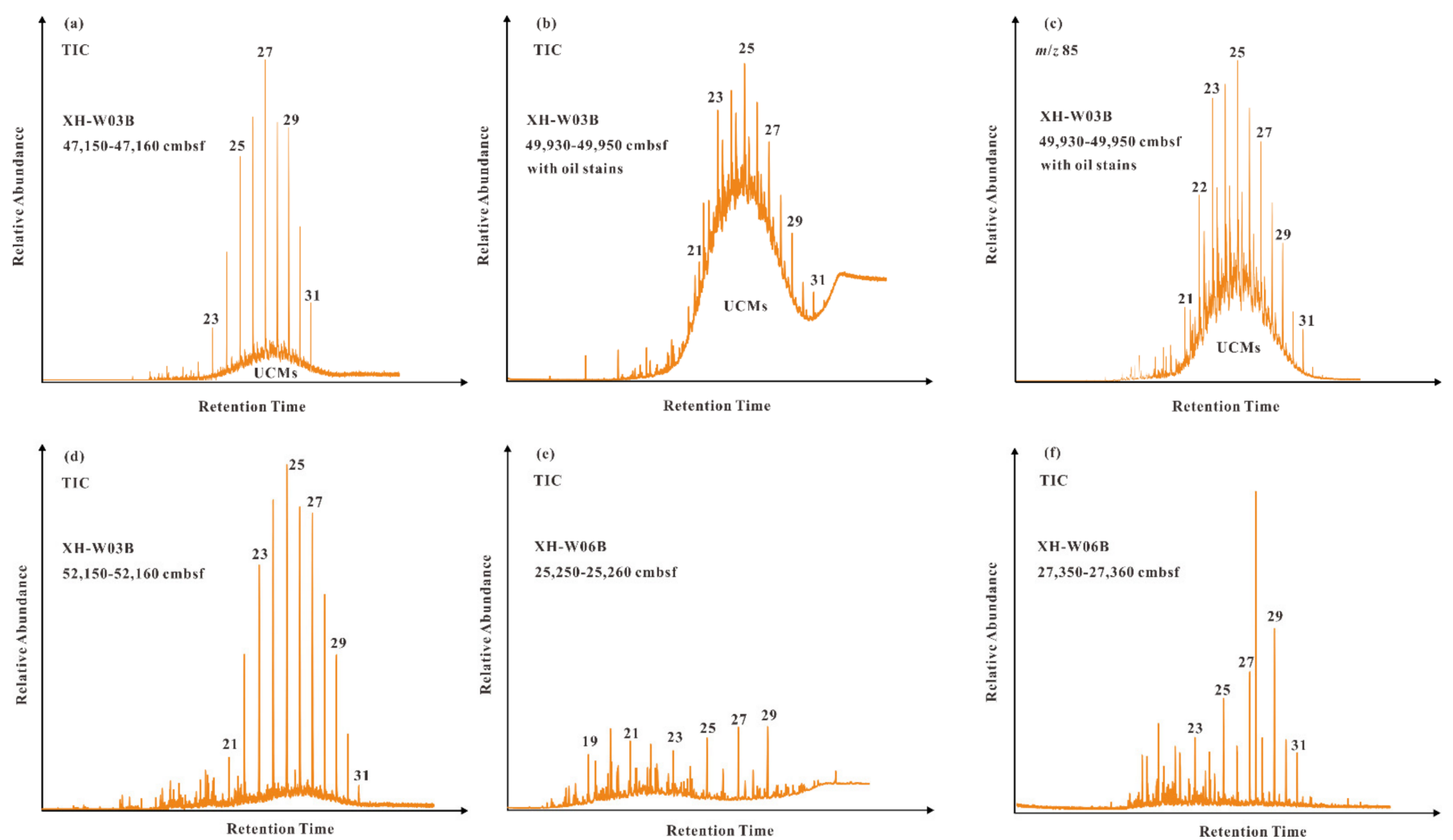

Figure 4. GC-MS chromatograms showing the distribution of $n$-alkanes in sediments from (a-d) core GMGS4-XH-W03B and $(\mathbf{e}, \mathbf{f})$ core GMGS4-XH-W06B. $(\mathbf{a}, \mathbf{b})$ and $(\mathbf{d}-\mathbf{f})$ represent total ions chromatograms; (c) represent chromatogram of fragment ion $m / z$ 85. Arabic numerals indicate the numbers of carbon atoms.

The $n$-alkanoic acids mainly range from $C_{12}$ to $C_{22}$ in most of the samples and longchain $n$-alkanoic acids $\left(C_{24}\right.$ to $\left.C_{30}\right)$ only occur in a few samples (Table 2; Figure 5). Overall, the distribution of $n$-alkanoic acids in the studied samples is similar, and characterized by the dominance of short-chain $n$-alkanoic acids with a maximum at $C_{16}$ and significant even-over-odd carbon number predominance. Unsaturated fatty acids such as $C_{18: 1 \omega 9}$ and $C_{22: 1 \omega 13}$ generally show extremely high abundances, even higher than those of their adjacent saturated fatty acids. Branched fatty acids, including iso- $\mathrm{C}_{14: 0}$, iso- $\mathrm{C}_{15: 0}$, anteiso$\mathrm{C}_{15: 0}$, and iso- $\mathrm{C}_{16: 0}$, are detected in sample 2 and sample 4 . Notably, iso- $\mathrm{C}_{15: 0}$ and anteiso$\mathrm{C}_{15: 0}$ are considered as two specific biomarkers for sulfate reducing bacteria [32]; and the calculated $i-\mathrm{C}_{15: 0}+a i-\mathrm{C}_{15: 0} / \mathrm{C}_{15: 0}$ ratio in sample 2 with oil stains and sample 4 are 1.1 and 0.4 , respectively (Table 2; Figure 5).

The $n$-alkanols in all samples generally range from $C_{16}$ to $C_{28}$, with a maximum at $\mathrm{C}_{22}, \mathrm{C}_{24}$, and $\mathrm{C}_{28}$ (Table 2; Figure 6). Similar to $n$-alkanoic acids, the $n$-alkanols also show a significant even-over-odd carbon number predominance (Figure 6). Meanwhile, a series of steroids (sterols and stanols) were detected in all the samples but with relatively low abundances. 

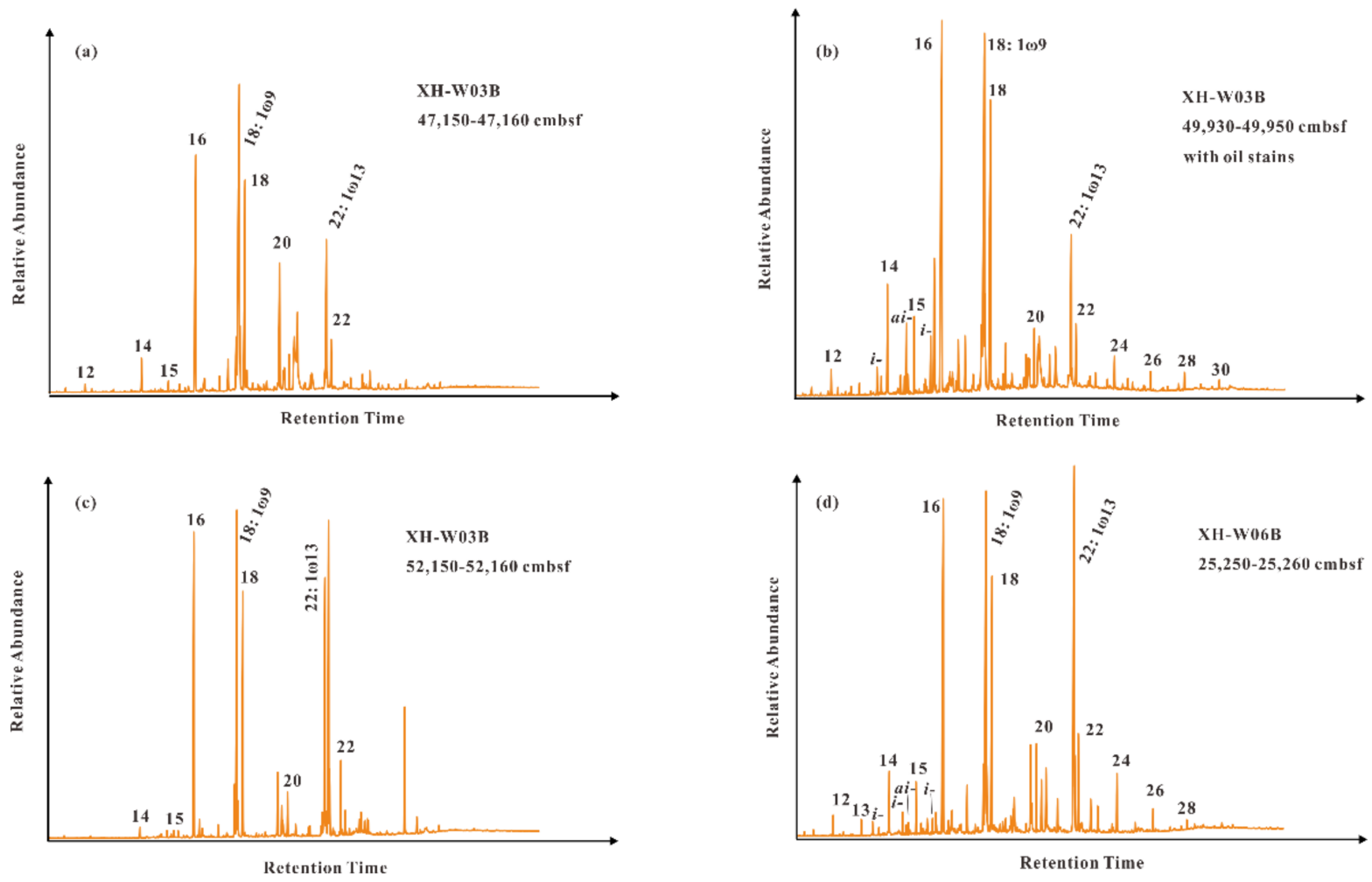

Figure 5. GC-MS chromatograms showing the distribution of fatty acids in sediments from (a-c) core GMGS4-XH-W03B

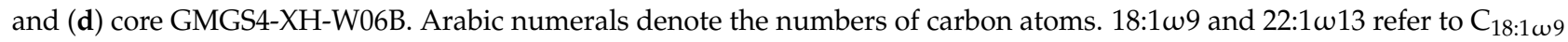

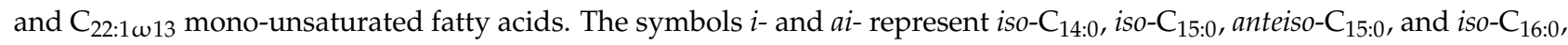
respectively.
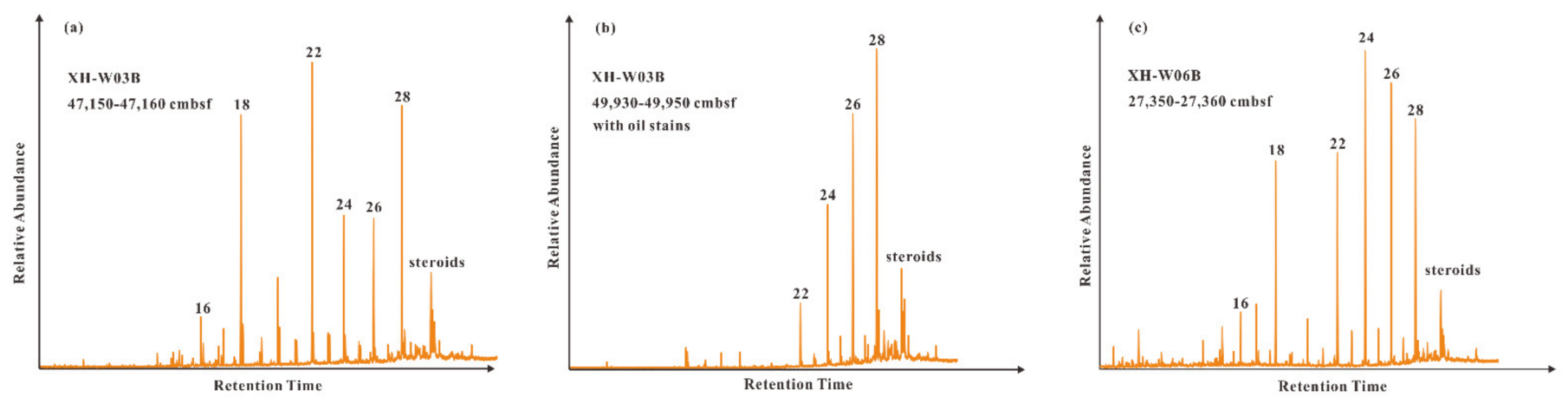

Figure 6. GC-MS chromatograms showing the distribution of $n$-alkanols and steroids in sediments from (a,b) core GMGS4XH-W03B and (c) core GMGS4-XH-W06B. Arabic numerals indicate the numbers of carbon atoms.

\section{Discussion}

\subsection{Source Indication of Organic Matter in Sediments}

The source of organic matter in marine sediments has been frequently investigated using bulk organic matter parameters [28,33-35]. Multiple indices have been applied to track the source of organic matter, specifically the $\mathrm{C} / \mathrm{N}$ ratios together with $\delta^{13} \mathrm{C}$ and $\delta^{15} \mathrm{~N}$ values are widely used to distinguish between terrestrial and marine sources of sedimentary organic matter $[34,36]$. For instance, the $\mathrm{C} / \mathrm{N}$ ratios within $4-9$ indicate marine algae as the main source of organic matter; while those higher than 20 are taken as an indicator for evaluating the contribution of terrestrial organic matter $[33,37]$. Therefore, the $\mathrm{C} / \mathrm{N}$ ratios (3.46-6.00) indicate that the main source in the studied sediments is marine organic matter. Notably, the $\mathrm{C} / \mathrm{N}$ ratios are comparable to those reported previously for 
the hydrate-bearing sediments (5.79-6.75) in the Taixinan Basin of the SCS [19], while are obviously lower than those in the surface sediments (7.3-11.0) from the northern SCS [38].

In contrast to the $\mathrm{C} / \mathrm{N}$ ratios, the $\delta^{13} \mathrm{C}$ values may indicate the source of sedimentary organic matter more accurately [39]. The $\delta^{13} \mathrm{C}$ values are commonly applied to identify between terrestrial and marine sources of organic matter in marine environments. Generally, the $\delta^{13} \mathrm{C}$ values of marine organic matter are at the interval of $-22 \%$ to $-19 \%$; whereas terrestrial organic matter are isotopically lighter than its marine counterpart, typically within the range of $-28 \%$ to $-26 \%$ o $[40,41]$. Therefore, the $\delta^{13} \mathrm{C}$ values $(-23.65 \%$ o to $-21.81 \%$ o) suggest that the sedimentary organic matter in this study are primarily of marine origin but with a minor contribution of terrestrial plants. Furthermore, it has been reported that the plot between $\mathrm{C} / \mathrm{N}$ ratios and $\delta^{13} \mathrm{C}$ values is an effective tool for qualitatively analyzing the sources of organic matter [28]. As illustrated in Figure 7a, the C/NFigure ratios and $\delta^{13} \mathrm{C}$ values in the studied sediments fall in the mixed range of different organic matter derived from marine algae, marine particulate organic carbon (POC), and bacteria.
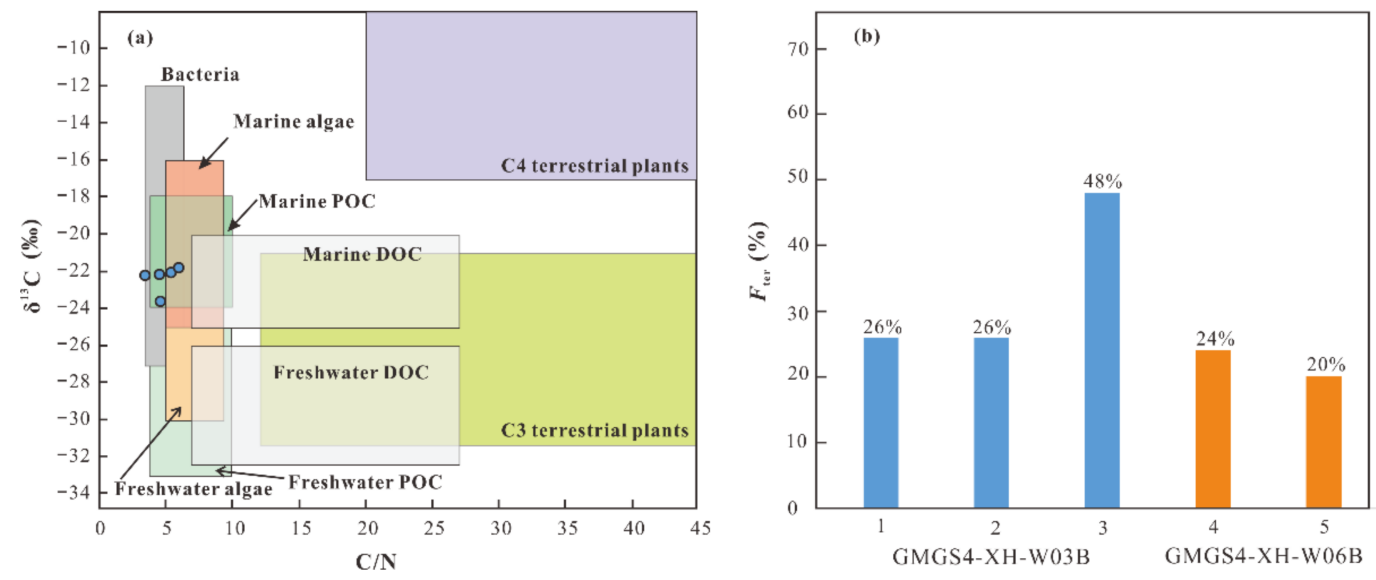

Figure 7. (a) Source indication inferred from the $\delta^{13} \mathrm{C}$ values and $\mathrm{C} / \mathrm{N}$ ratios of organic matter. Adapted with permission from ref. [28]. Copyright 2006 Clearance Center; (b) calculated percentages of terrestrial organic matter $\left(F_{\text {ter }}\right)$ in sediments. POC and DOC denote particulate organic carbon and dissolved organic carbon, respectively.

To distinguish the sources of organic matters more accurately, a two end-member model was employed in this study for quantitatively assessing the contribution of terrestrial and marine organic matter according to their $\delta^{13} \mathrm{C}$ values $[34,42]$ :

$$
F_{\text {ter }}(\%)=\left[\delta^{13} C_{\text {sam }}-\delta^{13} C_{\text {mar }}\right] /\left[\delta^{13} C_{\text {ter }}-\delta^{13} C_{\text {mar }}\right] \times 100
$$

where $F_{\text {ter }}(\%)$ and $\delta^{13} \mathrm{C}_{\text {sam }}$ represent the percentages of terrestrial organic matter and measured $\delta^{13} \mathrm{C}$ values of samples, respectively; and $\delta^{13} C_{\text {mar }}$ and $\delta^{13} C_{\text {ter }}$ represent the marine and terrestrial end members, respectively.

For the studied area, we adopted $-27 \%$ and $-20.5 \%$ as the terrestrial and marine end-member values respectively, as reported by $\mathrm{Hu}$ et al. [34]. The calculated relative percentages of terrestrial organic matter in the studied sediments are presented in Table 2 and Figure $7 \mathrm{~b}$. The estimated result (the ratios at the interval of $20 \%$ to $48 \%$ ) indicates that the contribution of terrestrial organic matter is relatively low (except sample 3 from core GMGS4-XH-W03B), which is consistent with the conclusion mentioned above.

Likewise, the $\delta^{15} \mathrm{~N}$ values vary significantly among different sources, and are also used as a proxy of the provenance of organic matter in marine sediments [42]. It is well-known that terrestrial organic matter show a lower $\delta^{15} \mathrm{~N}$ value than that of marine organic matter, because marine planktons generally use isotopically heavier nitrates as their nitrogen source in comparison with terrestrial plants. For instance, the typical $\delta^{15} \mathrm{~N}$ values of terrestrial vascular plants range from $-5 \%$ to $18 \%$ with the mean value of $\sim 3 \%$ [34]. Liu [35] 
further reported that the $\delta^{15} \mathrm{~N}$ values of terrestrial $\mathrm{C} 3$ and $\mathrm{C} 4$ plants were in the ranges of $5-18 \%$ and 3-6\%, respectively. As we know, the average $\delta^{15} \mathrm{~N}$ value of marine nitrate is about 5\% [43]; the average $\delta^{15} \mathrm{~N}$ value of marine POC is in the range of 3-12\%o with an average value of $6 \%$ [34]; and the $\delta^{15} \mathrm{~N}$ values of organic nitrogen produced by nitrogenfixing microorganisms and phytoplankton are at the intervals of $0-2 \%$ and $5.5-8.5 \%$, respectively [44,45]. In addition, the $\delta^{15} \mathrm{~N}$ values of sediments from the subtropical Pearl River estuary and adjacent shelf, the South China range from $3.9 \%$ to $6.4 \%$ [34], which is comparable to the obtained values (3.43-5.08\%) in this study. Overall, in combination with the $\mathrm{C} / \mathrm{N}$ ratios and $\delta^{13} \mathrm{C}$ values, the $\delta^{15} \mathrm{~N}$ values also reflect the dominance of marine organic matter. Meanwhile, the strong positive correlation between the $\delta^{13} \mathrm{C}$ and $\delta^{15} \mathrm{~N}$ values in the studied samples reflects that there might be a high proportion of labile organic matter in freshly supplied marine organic material [46].

\subsection{Origin of Lipid Biomarkers in Sediments}

As mentioned above, the $\mathrm{C} / \mathrm{N}$ ratios and $\delta^{13} \mathrm{C}$ and $\delta^{15} \mathrm{~N}$ values have long been recognized for its important role in tracing the source input of sedimentary organic matter. However, the source of organic matter in marine sediments is not well understood due to the complexity of source inputs and biogeochemical processes such as biodegradation [47]. Therefore, accurately tracing the source input of sedimentary organic matter has long been a research focus. In fact, biomarkers originated from multiple source inputs are of indispensable advantage in precisely identifying the origin and provide complementary data for identifying the source input, because they are chemically stable from the bio-precursor molecules, even after decomposition and diagenesis [27]. In addition, the application of multi-biomarker molecules (i.e., $n$-alkanes, $n$-alkanols, steroids and fatty acids) with mutually confirmable information is capable of stricter constraining the sources, in particular for marine environments with complex source inputs [19].

On the whole, the distribution patterns of $n$-alkanoic acids and $n$-alkanols in two core samples are basically similar, but $n$-alkanes are obviously different between cores GMGS4-XH-W03B and GMGS4-XH-W06B. In most of the samples, the dominance of medium-chain $n$-alkanes with a maximum at $n-\mathrm{C}_{25}$ reflects a large source input of aquatic plants [25]. The predominance of long-chain $n$-alkanes with maxima at $n-C_{27}$ and $n-C_{29}$ suggests that terrestrial higher plants may be dominant [48]. It should be noted that algae (i.e., Botryococcus braunii race A) can also produce odd numbered long-chain nalkanes $[26,49]$. In this study, UCMs were detected in most of the sediments from core GMGS4-XH-W03B, especially sample 2 with oil stains, implying that these sediments were likely contaminated with petroleum hydrocarbons $[6,27,50]$. It is notable that UCMs are ubiquitous in microbially degraded crude oil, and commonly ascribed to the occurrence of hydrocarbons related with oil pollution or petroleum seepage [6,27]. In addition, UCMs have frequently been observed in authigenic seep carbonates from the Gulf of Mexico and the SCS where oil seepage occurred [17,51]. Furthermore, $n$-alkane parameters, including $\mathrm{CPI}$ and OEP ratios are generally about 1.0 in the samples from core GMGS4-XH-W03B, implying a relatively high thermal maturity, because the petroleum source of organic matter input or hydrocarbon leakage from underlying high-maturity source formations generally exhibits CPI and OEP ratios around 1.0 [52]; whereas the CPI (2.33 to 2.92) and OEP (1.97 to 1.98) ratios, together with the odd-over-even predominance and small UCMs in the sediments from core GMGS4-XH-W06B are characteristics of modern sediments. Notably, our team also conducted organic geochemical analysis in gas hydrate sediments from the Shenhu area [7] and the Taixinan area [19,53] of the SCS. In our previous studies, we reported the wide occurrence of UCMs and OEP values around 1.0 in both shallow and deeply-buried hydrate-bearing sediments from the SCS $[7,19,53]$. Adopting the technique of GC $\times$ GC-TOFMS, 25-norhopane, pristane, phytane and hopanes were further identified [7]. Unfortunately, terpanes and steranes are undetectable in this study, but the presence of UCMs, associated with CPI and OEP ratios, provides important evidence for supporting the source input of petroleum hydrocarbons in the sediments from core GMGS4-XH-W03B. 
For $n$-alkanoic acids, the samples were generally characterized by the dominance of short-chain $n$-alkanoic acids with a maximum at $C_{16}$ and the significant even-over-odd carbon number predominance, showing the low concentrations of long-chain $n$-alkanoic acids. Short-chain $n$-alkanoic acids are nonspecific biomarkers for source identification since their widespread occurrence in marine fauna, bacteria, microalgae, and higher plants [54,55], however the absence or extremely low concentrations of long-chain $n$-alkanoic acids indicates an insignificant contribution of terrestrial plants. Monounsaturated fatty acids, dominated by $\mathrm{C}_{18: 1 \omega 9}$ ( $\omega$ represents the number of double bonds) and $\mathrm{C}_{22: 1 \omega 13}$ ), were detected with a relatively high abundance second only to the maximum component $\left(\mathrm{C}_{16}\right)$. These characteristics indicate a large input of organic matters from microalgae and zooplanktons [56-59]. Further, branched fatty acids, including iso- $\mathrm{C}_{14: 0}$, iso- $\mathrm{C}_{15: 0}$, anteiso- $\mathrm{C}_{15: 0}$, and iso- $\mathrm{C}_{16: 0}$ are discriminated from in two of these samples, especially sample 2 with oil stains. Generally, these compounds are considered to be mainly bacterial sources [32,60]; and the relatively high abundances of $i s o-C_{15: 0}$ and anteiso- $C_{15: 0}$ in the sample with oil stains reflect that sulfate reducing bacteria may primarily thrive on petroleum hydrocarbons [32,61-63].

In this study, the $n$-alkanols in all samples generally range from $C_{16}$ to $C_{28}$, with the maximum at $\mathrm{C}_{22}, \mathrm{C}_{24}$, and $\mathrm{C}_{28}$. Usually, the high abundances of even-odd-distributed long-chain $n$-alcohols (i.e., $\mathrm{C}_{24}$ and $\mathrm{C}_{28}$ ) seem to indicate a contribution of organic matter from terrestrial higher plants [50,64], whereas the short-chain $n$-alcohols $\left(<C_{22}\right)$, in comparable abundances to the long-chain $n$-alcohols, are considered to be derived from marine planktons, diatoms, and bacteria $[65,66]$. Steroids (sterols and stanols), as particularly useful biomarkers for assessing the source of organic matter in aquatic ecosystems [67,68], are detected in all the samples but with relatively low abundances. Unfortunately, no specific sterols and stanols were identified due to their low abundances and co-elution with adjacent compounds. Overall, the composition and distribution of various biomarkers suggest that the original source inputs of organic matters in the studied samples are multiple, including marine planktons, terrestrial plants, and bacteria. Notably, based on the occurrence of oil stains in sample 2 and big UCMs as well as the CPI and OEP values in all samples from core GMGS4-XH-W03B, the petroleum hydrocarbons migrated from underlying high-maturity reservoirs may be a source input of organic matter. In summary, the bulk organic geochemical parameters and various lipid biomarkers jointly indicate that marine organic matter are a dominant source input for the autochthonous organic matter; and the discrepancy in the source interpretation among $n$-alkanes, fatty acids (i.e., $n$-alkanoic acids and branched fatty acids), and $n$-alkanols may be due to multiple possible sources for some molecules.

\subsection{Geochemical Implications on Underlying Petroleum/Gas Reservoirs}

Upward migration of petroleum hydrocarbons is generally regarded as a window for tracing deep petroleum/gas reservoirs. As discussed in Section 3.2, the evident biomarker signatures (including the CPI and OEP values around 1.0 and occurrence of big UCMs) associated with petroleum hydrocarbons were identified from core GMGS4-XH-W03B. As reported previously that the Xisha area is adjacent to many oil/gas fields, including the Pearl River Mouth Basin, Beibuwan Basin, Yinggehai Basin, Qiongdongnan Basin, and Taixinan Basin [2,3,8]. In terms of the geological and tectonic evolution in these areas, they have a close relationship and share the similar characteristics [10]. In addition, it is widely acknowledged that the high-quality source rocks for generating hydrocarbons formed in the Eocene-Oligocene rift in the Xisha area, in particular the sedimentary sequences characterized by lacustrine and neritic mudstone facies and coastal plain coal-bearing layers [21]. Further, the high sedimentation rate and geothermal gradient $\left(72-89^{\circ} \mathrm{C} / \mathrm{km}\right)$ are extremely favorable for the maturation of organic matters and hydrocarbon generation. The discoveries of BSRs [9] and mega pockmarks (1000-2500 $\mathrm{m}$ in diameter and $60-140 \mathrm{~m}$ in depth) in this region [20,21], reflect the occurrence of structures associated with the underlying fluid migration [69]. Apparently, the occurrence of these structures 
such as unconformities, active faults, and diapirs supports the inference that petroleum hydrocarbons were migrated from underlying oil/gas reservoirs.

As a whole, the organic geochemical results, mainly including biomarker distribution patterns and compositions in sediments from core GMGS4-XH-W03B provide a new clue for evaluating the potential of underlying petroleum reservoirs in the Xisha area. The geological backgrounds and tectonic activities also confirmed the possibility of the generation and migration of petroleum hydrocarbons in this area. Similarly, the molecular evidence reflecting the contribution of petroleum hydrocarbons from deep oil reservoirs was reported in the Shenhu area [7] and Taixinan Basin [11,19,53]. These results reveal that the migration of petroleum hydrocarbons is a common phenomenon in the SCS; and the studies on the bulk organic matter and lipid biomarkers are reliable approaches for seeking the migration of petroleum hydrocarbons from deep petroleum/gas reservoirs. Unfortunately, our newly-obtained biomarker evidence is still unlikely to confirm whether gas hydrates exist or not, despite gas hydrates and conventional petroleum/gas reservoirs generally coexist in the SCS. It is notable that the sulfate-methane interface (SMI) depth can reflect the existence of underlying gas hydrates, i.e., a relatively shallow SMI depth (generally $<10 \mathrm{mbsf}$ ) above hydrate deposits [70]. Considering the SMI depths of $70 \mathrm{~m}$ and $150 \mathrm{~m}$ in these cores, together with the absence of the specific biomarkers associated with methanotrophic archaea, it is not easy for gas hydrate systems to develop in the Xisha area.

\section{Materials and Methods}

\subsection{Sampling}

Two sediment cores for gas hydrate drilling expeditions (GMGS4) were collected in 2016 from the Xisha area (Figure 1) at the stations GMGS4-XH-W03B (1777 m water depth; $72{ }^{\circ} \mathrm{C} / \mathrm{km}$ geothermal gradients) and GMGS4-XH-W06B (1923 m water depth; $89^{\circ} \mathrm{C} / \mathrm{km}$ geothermal gradients). The depths of sulfate-methane interface (SMI) for sediment cores GMGS4-XH-W03B and GMGS4-XH-W06B are $70 \mathrm{~m}$ and $150 \mathrm{~m}$, respectively. Sediments from the two cores are yellowish gray, unconsolidated, and fine-grained silty clay. The samples were transported to the laboratory and stored at $-20^{\circ} \mathrm{C}$ until analysis. In this study, we selected 5 representative samples from deep sediments for organic geochemical analysis, including one sample with oil stains (i.e., sample 2) (Table 1).

\subsection{Experimental Analysis}

The TOC and TN contents, $\mathrm{C} / \mathrm{N}$ ratios, and $\delta^{13} \mathrm{C}$ and $\delta^{15} \mathrm{~N}$ values of sedimentary organic matters were measured by a CE EA1112 C/N elemental analyzer (CE Instruments, Wigan, UK)-Delta Plus XL stable isotope ratio mass spectrometry (Finnigan, Thermo Scientific, Waltham, MA, USA). Before analysis, carbonates were removed with $3 \mathrm{M} \mathrm{HCl}$, then washed with distilled water, and finally freeze-dried. Prior to the analysis, a standard (acetanilide) was measured for quality control, with the instrument precision deviations of both TOC and TN contents less than/equal to $0.10 \%$ abs. The $\delta^{13} \mathrm{C}$ and $\delta^{15} \mathrm{~N}$ values were reported in the delta $(\delta)$ notation relative to the V-PDB standard and atmospheric $\mathrm{N}_{2}$, respectively, with the corresponding standard deviations within $\pm 0.05 \%$ and $\pm 0.14 \%$ o respectively over the analytical course.

Freeze-dried samples were ground to less than 120 mesh; and about $20 \mathrm{~g}$ were Soxhletextracted with a mixture of dichloromethane/methanol $(3: 1, v / v)\left(48{ }^{\circ} \mathrm{C}, 72 \mathrm{~h}\right)$. After removing the extracted elemental sulfur, the fractions were dried with sodium sulfate and concentrated; and then the total lipid extracts were saponified with $\mathrm{KOH} /$ methanol solution $\left(1 \mathrm{M}, 70{ }^{\circ} \mathrm{C}, 2 \mathrm{~h}\right)$. The neutral fractions were extracted with $n$-hexane for 3-5 times; and fatty acids were extracted after acidification ( $\mathrm{HCl}, \mathrm{pH} 1-2)$. The neutral fractions were then subjected to column chromatography for obtaining saturated hydrocarbons, aromatics, and fatty alcohols using $n$-hexane, $n$-alkanes/dichloromethane $(4: 1 ; v / v)$ and dichloromethane/methanol $(1: 1 ; v / v)$ as elutions, respectively. The fatty alcohols and fatty acids were further converted into trimethylsiloxyl derivatives and fatty acids methyl esters (FAMEs) following a previous reference [71]. 
Gas chromatography-mass spectrometry (GC-MS) analysis for saturated hydrocarbons, fatty alcohols, and fatty acids were performed on an Agilent 7890A gas chromatograph coupled with a 5975C mass spectrometer (Agilent Technologies, Palo Alto, CA, USA). Separation was achieved with the HP-5 MS fused a silica capillary column $(30 \mathrm{~m} \times 0.25 \mathrm{~mm}$ i.d. $\times 0.25 \mu \mathrm{m})$. Helium was used as the carrier gas with a flow rate of $1.0 \mathrm{~mL} / \mathrm{min}$. The injector and detector temperatures were set at $290^{\circ} \mathrm{C}$ and $300^{\circ} \mathrm{C}$, respectively; and $2 \mu \mathrm{L}$ of each concentrated sample were injected in the splitless mode. The oven temperature was initially set at $80^{\circ} \mathrm{C}$ (held for $5 \mathrm{~min}$ ); and then programmed at $3{ }^{\circ} \mathrm{C} / \mathrm{min}$ to $290{ }^{\circ} \mathrm{C}$ (held for $20 \mathrm{~min}$ ). The ion source was operated in the electron impact (EI) mode at $70 \mathrm{eV}$; and the full scan mass spectra were adopted. The compound assignment was compared to the NIST11 library of mass spectra as well as with the published data.

\section{Conclusions}

The features of $\mathrm{C} / \mathrm{N}$ ratios, $\delta^{13} \mathrm{C}$ and $\delta^{15} \mathrm{~N}$ values, and biomarker distributions ( $n$ alkanes, $n$-alkanols, steroids and fatty acids) in deep sediments from cores GMGS4-XHW03B and GMGS4-XH-W06B in the Xisha area, the SCS are investigated. The bulk organic $\mathrm{C} / \mathrm{N}$ ratios and stable $\mathrm{C}-\mathrm{N}$ isotope values $\left(\delta^{13} \mathrm{C}\right.$ and $\left.\delta^{15} \mathrm{~N}\right)$ for the studied samples indicate a dominance of marine algae and bacteria inputs but a low input of terrestrial plants. The source indication from biomarker signatures is generally in accord with the bulk geochemical parameters, showing an immature source with marine organic matter dominated, i.e., the small UCMs, high OEP and CPI values of $n$-alkanes, dominance of short-chain $n$-alkanoic acids $\left(\mathrm{C}_{16}-\mathrm{C}_{22}\right)$ and mid-/long-chain $n$-alkanols $\left(\mathrm{C}_{22}-\mathrm{C}_{28}\right)$ with a significant even-over-odd carbon number predominance, high abundance of monounsaturated fatty acids $C_{18: 1 \omega 9}$ and $C_{22: 1 \omega 13}$, and occurrence of steroids. However, the $n$-alkanes in the sediments from core GMGS4-XH-W03B exhibit mature petroleum characteristics, i.e., big UCMs (especially sample 2 with oil stains) and OEP and CPI values around 1.0. Considering the high sedimentary rate and geothermal gradient as well as tectonic activities, the migration of petroleum hydrocarbons from underlying oil/gas reservoirs are plausible. Overall, our results may provide valuable information for evaluating the potential of hydrocarbon resources and reflecting the existence of underlying petroleum reservoirs in the Xisha area, the SCS.

Author Contributions: Conceived and designed the experiments: J.-H.W. and Y.-X.F.; Sampling: Y.L., Q.-Z.Z., X.-P.X. and Y.-X.F.; Performed experiments: Y.L., J.-Z.L. and X.-P.X.; Wrote the paper: Y.L. and J.-H.W.; and Modified the manuscript: J.-H.W. All authors have read and agreed to the published version of the manuscript.

Funding: This study was financially supported by the National Natural Science Foundation of China (Grant No. 41703043), Guangdong Major Project of Basic and Applied Basic Research (Grant No.2020B0301030003), Guangdong Research and Construction of Public Service Abilities (Grant No. 2017B020218004), China Geological Survey Project (Grant No. DD20190230), Strategic Priority Research Program of Chinese Academy of Sciences (Grant No. XDA14010102).

Institutional Review Board Statement: Not Applicable.

Informed Consent Statement: Not Applicable.

Data Availability Statement: The data used to support the findings of this study are available from the corresponding author upon request.

Acknowledgments: The authors would like to thank Zhi-Guang Song and Guo-Yi Zhou for their assistance in organic geochemical analysis. The authors would also like to thank Nina Kupresanin and three anonymous reviewers for their constructive comments and suggestions.

Conflicts of Interest: The authors declare no conflict of interest.

Sample Availability: Samples of the compounds are not available from the authors. 


\section{References}

1. Taylor, B.; Hayes, D.E. Origin and history of the South China Sea Basin. In The Tectonic and Geologic Evolution of Southeast Asian Seas and Islands: Part 2; Wiley: Hoboken, NJ, USA, 1983; Volume 27, pp. $23-56$.

2. Jiang, H.; Pang, X.; Shi, H.; Yu, Q.; Cao, Z.; Yu, R.; Chen, D.; Long, Z.; Jiang, F. Source rock characteristics and hydrocarbon expulsion potential of the Middle Eocene Wenchang formation in the Huizhou depression, Pearl River Mouth basin, South China Sea. Mar. Pet. Geol. 2015, 67, 635-652. [CrossRef]

3. He, D.; Hou, D.; Zhang, P.; Harris, M.; Mi, J.; Chen, T.; Li, J. Reservoir characteristics in the LW3-1 structure in the deepwater area of the Baiyun sag, South China Sea. Arabian J. Geosci. 2016, 9, 251. [CrossRef]

4. Dai, J.X.; Ni, Y.Y.; Huang, S.P.; Peng, W.L.; Han, W.X.; Gong, D.Y.; Wei, W. Genetic types of gas hydrates in China. Pet. Explor. Dev. 2017, 44, 887-898. [CrossRef]

5. Feng, D.; Qiu, J.; Hu, Y.; Peckmann, J.; Guan, H.; Tong, H.; Chen, C.; Chen, J.; Gong, S.; Li, N.; et al. Cold seep systems in the South China Sea: An overview. J. Asian Earth Sci. 2018, 168, 3-16. [CrossRef]

6. Zhu, X.; Mao, S.; Sun, Y.; Jia, G.; Wu, N.; Wu, D.; Guan, H.; Yan, W. Organic molecular evidence of seafloor hydrocarbon seepage in sedimentary intervals down a core in the northern South China Sea. J. Asian Earth Sci. 2018, 168, 155-162. [CrossRef]

7. Zhou, Q.Z.; Li, Y.; Chen, F.; Li, S.F.; Dong, S.J.; Zhang, F.L.; Xu, X.M.; Wang, J.H. Geochemical significance of biomarkers in the methane hydrate-bearing sediments from the Shenhu area, the South China Sea. Molecules 2019, 24, 456. [CrossRef]

8. Wang, J.; Wu, S.; Yao, Y. Quantifying gas hydrate from microbial methane in the South China Sea. J. Asian Earth Sci. 2018, 168, 48-56. [CrossRef]

9. Wang, X.; Wu, S.; Yuan, S.; Wang, D.; Ma, Y.; Yao, G.; Gong, Y.; Zhang, G. Geophysical signatures associated with fluid flow and gas hydrate occurrence in a tectonically quiescent sequence, Qiongdongnan Basin, South China Sea. Geofluids 2010, 10, 351-368. [CrossRef]

10. Zhang, G.X.; Liang, J.Q.; Lu, J.A.; Yang, S.X.; Zhang, M.; Holland, M.; Schultheiss, P.; Su, X.; Sha, Z.B.; Xu, H.N.; et al. Geological features, controlling factors and potential prospects of the gas hydrate occurrence in the east part of the Pearl River Mouth Basin, South China Sea. Mar. Pet. Geol. 2015, 67, 356-367. [CrossRef]

11. Gong, J.; Sun, X.; Xu, L.; Lu, H. Contribution of thermogenic organic matter to the formation of biogenic gas hydrate: Evidence from geochemical and microbial characteristics of hydrate-containing sediments in the Taixinan Basin, South China Sea. Mar. Pet. Geol. 2017, 80, 432-449. [CrossRef]

12. McDonnell, S.L.; Max, M.D.; Cherkis, N.Z.; Czarnecki, M.F. Tectono-sedimentary controls on the likelihood of gas hydrate occurrence near Taiwan. Mar. Pet. Geol. 2000, 17, 929-936. [CrossRef]

13. Wu, S.; Zhang, G.; Huang, Y.; Liang, J.; Wong, H.K. Gas hydrate occurrence on the continental slope of the northern South China Sea. Mar. Pet. Geol. 2005, 22, 403-412. [CrossRef]

14. Chen, F.; Su, X.; Lu, H.F.; Zhou, Y.; Zhuang, C. Relations between biogenic component (foraminifera) and highly saturated gas hydrates distribution from Shenhu area, Northern South China Sea. Earth Sci. 2013, 38, 907-915. (In Chinese)

15. Feng, J.C.; Wang, Y.; Li, X.S.; Li, G.; Zhang, Y.; Chen, Z.Y. Production performance of gas hydrate accumulation at the GMGS2-Site 16 of the Pearl River Mouth Basin in the South China Sea. J. Nat. Gas Sci. Eng. 2015, 27, 304-320. [CrossRef]

16. Jiao, L.; Su, X.; Wang, Y.; Jiang, H.; Zhang, Y.; Chen, F. Microbial diversity in the hydrate-containing and -free surface sediments in the Shenhu area, South China Sea. Geosci. Front. 2015, 6, 627-633. [CrossRef]

17. Guan, H.; Birgel, D.; Peckmann, J.; Liang, Q.; Feng, D.; Yang, S.; Liang, J.; Tao, J.; Wu, N.; Chen, D. Lipid biomarker patterns of authigenic carbonates reveal fluid composition and seepage intensity at haima cold seeps, South China Sea. J. Asian Earth Sci. 2018, 168, 163-172. [CrossRef]

18. Xiong, P.; Lu, H.; Xie, X.; Zhang, G.; Fu, S.; Jiang, L.; Zhang, P. Geochemical responses and implications for gas hydrate accumulation: Case study from site SHC in Shenhu Area within northern South China Sea. Mar. Pet. Geol. 2020, 111, 650-661. [CrossRef]

19. Li, Y.; Fang, Y.X.; Zhou, Q.Z.; Xu, X.P.; Liu, J.Z.; Zhou, G.Y.; Wang, J.H. Geochemical insights into contribution of petroleum hydrocarbons to the formation of hydrates in the Taixinan Basin, the South China Sea. Geosci. Front. 2021, 12, 100974. [CrossRef]

20. Luo, M.; Chen, L.; Wang, S.; Yan, W.; Wang, H.; Chen, D. Pockmark activity inferred from pore water geochemistry in shallow sediments of the pockmark field in southwestern Xisha Uplift, northwestern South China Sea. Mar. Pet. Geol. 2013, 48, 247-259. [CrossRef]

21. Luo, M.; Dale, A.W.; Wallmann, K.; Hensen, C.; Gieskes, J.; Yan, W.; Chen, D.F. Estimating the time of pockmark formation in the SW Xisha Uplift (South China Sea) using reaction-transport modelling. Mar. Geol. 2015, 364, 21-31. [CrossRef]

22. Zhang, Y.; Luo, M.; Hu, Y.; Wang, H.; Chen, D. An Areal Assessment of Subseafloor Carbon Cycling in Cold Seeps and Hydrate-Bearing Areas in the Northern South China Sea. Geofluids 2019, 2, 1-14.

23. Bi, D.J.; Zhai, S.K.; Zhang, D.J.; Liu, X.F.; Liu, X.Y.; Jiang, L.J.; Zhang, A.B. Constraints of fluid inclusions and C, O isotopic compositions on the origin of the dolomites in the Xisha Islands, South China Sea. Chem. Geol. 2018, 493, 504-517. [CrossRef]

24. Wu, F.; Xie, X.; Betzler, C.; Zhu, W.; Zhu, Y.; Guo, L.; Ma, Z.; Bai, H.; Ma, B. The impact of eustatic sea-level fluctuations, temperature variations and nutrient-level changes since the Pliocene on tropical carbonate platform (Xisha Islands, South China Sea). Palaeogeogr. Palaeoclimatol. Palaeoecol. 2019, 514, 373-385. [CrossRef]

25. Ficken, K.J.; Li, B.; Swain, D.L.; Eglinton, G. An n-alkane proxy for the sedimentary input of submerged/floating freshwater aquatic macrophytes. Org. Geochem. 2000, 3, 745-749. [CrossRef] 
26. Grice, K.; Audino, M.; Alexander, R.; Boreham, C.J.; Kagi, R.I. Distributions and stable carbon isotopic compositions of biomarkers in torbanites from different palaeogeographical locations. Org. Geochem. 2001, 32, 1195-1210. [CrossRef]

27. Peters, K.E.; Walters, C.C.; Moldowan, J.M. The Biomarker Guide; Cambridge University Press: Cambridge, UK, 2005.

28. Lamb, A.L.; Wilson, G.P.; Leng, M.J. A review of coastal palaeoclimate and relative sea-level reconstructions using $\delta^{13} \mathrm{C}$ and $\mathrm{C} / \mathrm{N}$ ratios in organic material. Earth Sci. Rev. 2006, 75, 29-57. [CrossRef]

29. Barreca, S.; Mazzola, A.; Orecchio, S.; Tuzzolino, N. Polychlorinated biphenyls in sediments from Sicilian coastal area (Scoglitti) using automated soxhlet, GC-MS, and principal component analysis. Polycyclic Aromat. Compd. 2014, 34, 237-262. [CrossRef]

30. Bergamasco, A.; Culotta, L.; De Stefano, C.; Orecchio, S.; Sammartano, S.; Barreca, S. Composition, distribution, and sources of polycyclic aromatic hydrocarbons in sediments of the Gulf of Milazzo (Mediterranean Sea, Italy). Polycyclic Aromat. Compd. 2014, 34, 397-424. [CrossRef]

31. Orecchio, S.; Bianchini, F.; Bonsignore, R.; Blandino, P.; Barreca, S.; Amorello, D. Profiles and sources of PAHs in sediments from an open-pit mining area in the Peruvian andes. Polycyclic Aromat. Compd. 2016, 36, 429-451. [CrossRef]

32. Zhang, C.L.; Li, Y.L.; Wall, J.D.; Larsen, L.; Sassen, R.; Huang, Y.S.; Wang, Y.; Peacock, A.; White, D.C.; Horita, J.; et al. Lipid and carbon isotopic evidence of methane-oxidizing and sulfate-reducing bacteria in association with gas hydrates from the Gulf of Mexico. Geology 2002, 30, 239-242. [CrossRef]

33. Meyers, P.A. Organic geochemical proxies of paleoceanographic, paleolimnologic, and paleoclimatic processes. Org. Geochem. 1997, 27, 213-250. [CrossRef]

34. Hu, J.; Peng, P.; Jia, G.; Mai, B.; Zhang, G. Distribution and sources of organic carbon, nitrogen and their isotopes in sediments of the subtropical Pearl River estuary and adjacent shelf, Southern China. Mar. Chem. 2006, 98, 274-285. [CrossRef]

35. Liu, B.Z. The Studies on the Food Web Structures of Northern China Sea by Stable Isotopes Analysis. Ph.D. Thesis, Dalian Maritime University, Dalian, China, 2013. (In Chinese).

36. Yu, F.; Zong, Y.; Lloyd, J.M.; Huang, G.; Leng, M.J.; Kendrick, C.; Lamb, A.L.; Yim, W.W.S. Bulk organic $\delta^{13} \mathrm{C}$ and C/N as indicators for sediment sources in the Pearl River delta and estuary, southern China. Estuar. Coast. Shelf Sci. 2010, 87, 618-630. [CrossRef]

37. Yang, J.Y.; Chung, K.H.; Jin, Y.K.; Shin, K.H. Characterizing lipid biomarkers in methanotrophic communities of gas hydratebearing sediments in the sea of Okhotsk. Mar. Pet. Geol. 2011, 28, 1884-1898. [CrossRef]

38. Zhang, Y.L.; Kaiser, K.; Li, L.; Zhang, D.N.; Ran, Y.; Benner, R. Sources, distributions, and early diagenesis of sedimentary organic matter in the Pearl River region of the South China Sea. Mar. Chem. 2014, 158, 39-48. [CrossRef]

39. Arthur, J.M.M.C.; Tyson, R.V.; Thomson, J.; Mattey, D. Early diagenesis of marine organic matter: Alteration of the carbon isotopic composition. Mar. Geol. 1992, 105, 51-61.

40. Fontugne, M.R.; Jouanneau, J.M. Modulation of the particulate organic carbon flux to the ocean by a macrotidal estuary-evidence from measurements of carbon isotopes in organic matter from the Gironde system. Estuar. Coastal Shelf Sci. 1987, 24, 377-387. [CrossRef]

41. Boutton, T.W. Stable carbon isotope ratios of natural materials: II. In Atmospheric, Terrestrial, Marine, and Freshwater Environments; Coleman, D.C., Fry, B., Eds.; Carbon Isotopes Techniques; Academic Press Inc.: San Diego, CA, USA, 1991; pp. $173-185$.

42. Koziorowska, K.; Kuliński, K.; Pempkowiak, J. Sedimentary organic matter in two Spitsbergen fjords: Terrestrial and marine contributions based on carbon and nitrogen contents and stable isotopes composition. Cont. Shelf Res. 2016, 113, 38-46. [CrossRef]

43. Wu, Y.; Zhang, J.; Li, D.J.; Wei, H.; Lu, R.X. Isotope variability of particulate organic matter at the PN section in the East China Sea. Biogeochemistry 2003, 65, 31-49. [CrossRef]

44. Thunell, R.C.; Sigman, D.M.; Muller-Karger, F.; Astor, Y.; Varela, R. Nitrogen isotope dynamics of the Cariaco Basin, Venezuela. Glob. Biogeochem. Cycles 2004, 18, GB3001. [CrossRef]

45. Cai, D.L.; Li, H.Y.; Tang, Q.S.; Sun, Y. The establishment of trophic spectrum in the food web of the Yellow and East China Seas: Insights from the carbon-nitrogen isotope analysis. Sci. China-Sci. Life Sci. 2005, 35, 123-130. (In Chinese)

46. Hobson, K.A.; Welch, H.E. Determination of trophic relationships within a high Arctic marine food web using $\delta^{13} \mathrm{C}$ and $\delta^{15} \mathrm{~N}$ analysis. Mar. Ecol. Prog. Ser. 1992, 8, 9-18. [CrossRef]

47. Tao, K.; Xu, Y.; Wang, Y.; Wang, Y.; He, D. Source, sink and preservation of organic matter from a machine learning approach of polar lipid tracers in sediments and soils from the Yellow River and Bohai Sea, eastern China. Chem. Geol. 2021, 582, 120441. [CrossRef]

48. Eglinton, G.; Hamilton, R.J. Leaf epicuticular waxes. Science 1967, 156, 1322-1335. [CrossRef]

49. Liu, W.G.; Yang, H.; Wang, H.Y.; An, Z.S.; Wang, Z.; Leng, Q. Carbon isotope composition of long chain leaf wax n-alkanes in lake sediments: A dual indicator of paleoenvironment in the Qinghai-Tibet Plateau. Org. Geochem. 2015, 83, 190-201. [CrossRef]

50. Rodriguez, N.D.; Philp, R.P. Productivity and paleoclimatic controls on source rock character in the Aman Trough, north central Sumatra, Indonesia. Org. Geochem. 2012, 45, 18-28. [CrossRef]

51. Feng, D.; Birgel, D.; Peckmann, J.; Roberts, H.H.; Joye, S.B.; Sassen, R.; Liu, X.L.; Hinrichs, K.U.; Chen, D. Time integrated variation of sources of fluids and seepage dynamics archived in authigenic carbonates from Gulf of Mexico Gas Hydrate Seafloor Observatory. Chem. Geol. 2014, 385, 129-139. [CrossRef]

52. Freeman, K.H.; Colarusso, L.A. Molecular and isotopic records of C4, grassland expansion in the late Miocene. Geochim. Cosmochim. Acta 2001, 65, 1439-1454. [CrossRef] 
53. Li, Y.; Zhou, Q.Z.; Xu, X.P.; Liu, J.Z.; Zhou, G.Y.; Fang, Y.X.; Wang, J.H. Porewater geochemical and lipid biomarker signatures for anaerobic methane oxidation in the hydrate-bearing system from the Taixinan Basin, the South China Sea. J. Asian Earth Sci. 2020, 203, 104559. [CrossRef]

54. Volkman, J.K.; Jeffrey, S.W.; Nichols, P.D.; Rogers, G.I.; Garland, C.D. Fatty acid and lipid composition of 10 species of microalgae used in mariculture. J. Exp. Mar. Biol. Ecol. 1989, 128, 219-240. [CrossRef]

55. Budge, S.M.; Parrish, C.C. Lipid biogeochemistry of plankton, settling matter and sediments in Trinity Bay, Newfoundland. II. Fatty acids. Org. Geochem. 1998, 29, 1547-1559. [CrossRef]

56. Chuecas, L.; Riley, J.P. Component fatty acids of the total lipid of some marine phytoplankton. J. Mar. Biol. Assoc. 1969, 49, 97-116. [CrossRef]

57. Heras, X.; Grimalt, J.O.; Albaiges, J.; Julia, R.; Anadon, P. Origin and diagenesis of the organic matter in Miocenefreshwater lacustrine phosphates (Cerandya Basin, Eastern Pyrencos). Org. Geochem. 1989, 14, 667-677. [CrossRef]

58. Wakeham, S.G.; Beier, J.A. Fatty acid and sterol biomarkers as indicators of particulate matter source and alteration processes in the Black Sea. Deep Sea Res. Part A 1991, 38, 943-968. [CrossRef]

59. Graeve, M.; Kattner, G.; Hagen, W. Diet-induced changes in the fatty acid composition of Arctic herbivorous copepods: Experimental evidence of trophic markers. J. Exp. Mar. Biol. Ecol. 1994, 182, 97-110. [CrossRef]

60. Wakeham, S.G.; Canuel, E.A. Fatty acids and sterols of particulate matter in a brackish and seasonally anoxic coastal salt pond. Org. Geochem. 1990, 16, 703-713. [CrossRef]

61. Orcutt, B.; Boetius, A.; Elvert, M.; Samarkin, V.; Joye, S.B. Molecular biogeochemistry of sulfate reduction, methanogenesis and the anaerobic oxidation of methane at Gulf of Mexico cold seeps. Geochim. Cosmochim. Acta 2005, 69, 4267-4281. [CrossRef]

62. Orcutt, B.; Joye, S.B.; Kleindienst, S.; Knittel, K.; Ramette, A.; Reitz, A.; Samarkin, V.; Treude, T.; Boetius, A. Impact of natural oil and higher hydrocarbons on microbial diversity, distribution, and activity in Gulf of Mexico cold-seep sediments. Deep Sea Res. Part II 2010, 57, 2008-2021. [CrossRef]

63. Hu, Y.; Luo, M.; Chen, L.; Liang, Q.; Feng, D.; Tao, J.; Yang, S.; Chen, D. Methane source linked to gas hydrate system at hydrate drilling areas of the South China Sea: Porewater geochemistry and numerical model constraints. J. Asian Earth Sci. 2018, 168, 87-95. [CrossRef]

64. Collister, J.W.; Rieley, G.; Stern, B.; Eglinton, G.; Fry, B. Compound-specific $\delta^{13} \mathrm{C}$ analyses of leaf lipids from plants with differing carbon dioxide metabolisms. Org. Geochem. 1994, 21, 619-627. [CrossRef]

65. Blumer, M.; Guillard, R.R.L.; Chase, T. Hydrocarbons of marine phytoplankton. Mar. Biol. 1971, 8, 183-189. [CrossRef]

66. Volkman, J.K.; Barrett, S.M.; Blackburn, S.I.; Mansour, M.P.; Sikes, E.L.; Gelin, F. Microalgal biomarkers: A review of recent research developments. Org. Geochem. 1998, 29, 1163-1179. [CrossRef]

67. Volkman, J.K. A review of sterol markers for marine and terrigenous organic matter. Org. Geochem. 1986, 9, 83-99. [CrossRef]

68. Jaffé, R.; Mead, R.; Hernandez, M.E.; Peralba, M.C.; DiGuida, O.A. Origin and transport of sedimentary organic matter in two subtropical estuaries: A comparative, biomarker-based study. Org. Geochem. 2001, 32, 507-526. [CrossRef]

69. Sun, Q.; Wu, S.; Hovland, M.; Luo, P.; Lu, Y.; Qu, T. The morphologies and genesis of mega-pockmarks near the Xisha Uplift, South China Sea. Mar. Pet. Geol. 2011, 28, 1146-1156. [CrossRef]

70. Borowski, W.S.; Paull, C.K.; Ussler, W., III. Marine pore-water sulfate profiles indicate in situ methane flux from underlying gas hydrate. Geology 1996, 24, 655-658. [CrossRef]

71. Guan, H.; Sun, Y.; Zhu, X.; Mao, S.; Feng, D.; Wu, N.; Chen, D. Factors controlling the types of microbial consortia in cold-seep environments: A molecular and isotopic investigation of authigenic carbonates from the South China Sea. Chem. Geol. 2013, 354, 55-64. [CrossRef] 